\title{
PERANCANGAN PROGRAM SISTEM PAKAR BERBASISKAN WEB UNTUK REHABILITASI MEDIK PENDERITA SKOLIOSIS
}

\author{
Vita Megawati $^{1}$; Djunaidy Santoso ${ }^{2}$ \\ ${ }^{1}$ Mahasiswi Program Studi Teknik Informatika, Fakultas Teknologi Informasi, Universitas Tarumangara \\ ${ }^{2}$ Computer Science Department, School of Computer Science, Binus University \\ Jln. K. H. Syahdan No. 9 Palmerah Jakarta Barat 11480 \\ djunsan2002@yahoo.com
}

\begin{abstract}
The application program created in this research is a web-based expert system program for medical rehabilitation of patients with scoliosis. The program aims to make consultation between users and the experts. With the expert system method based on components of medical science this application can help achieve the goal, that is to make easier for people to recognize and prevent the occurrence of scoliosis, as well as to make easier for doctors making conclusions. Bu using this expert system, students can make decisions quickly when there are problems with Scoliosis disease.
\end{abstract}

Keywords: medical rehabilitation, scoliosis, expert system, web

\begin{abstract}
ABSTRAK
Program aplikasi yang dibuat adalah program sistem pakar berbasiskan web untuk rehabilitasi medik penderita skoliosis. Program ini bertujuan untuk melakukan konsultasi antara pengguna dengan pakar. Dengan metode sistem pakar berdasarkan komponen ilmu kedokteran dapat membantu mencapai tujuan, yaitu mempermudah manusia mengenal dan mencegah terjadinya penyakit skoliosis, sekaligus mempermudah dokter mengambil kesimpulan. Dengan adanya sistem pakar ini, mahasiswa bisa mengambil keputusan dengan cepat di saat ada permasalahan dengan penyakit Skoliosis.
\end{abstract}

Kata kunci: rehabilitasi medik, skoliosis, sistem pakar, web 


\section{PENDAHULUAN}

Kecerdasan buatan merupakan salah satu bidang dalam ilmu komputer yang ditujukan pada pembuatan perangkat lunak dan perangkat keras sehingga dapat berfungsi sebagai sesuatu yang dapat berpikir seperti manusia. Dengan memahami mekanisme penalaran seperti manusia, diharapkan komputer benar-benar merupakan alat bantu yang berguna dalam memecahkan masalah yang memerlukan penalaran.

Salah satu cabang dari kecerdasan buatan yang akhir-akhir ini mengalami perkembangan adalah sistem pakar (expert system). Sistem pakar akan memberikan pemecahan suatu masalah yang didapat dari dialog dengan pakar. Dengan bantuan sistem pakar, seseorang yang bukan pakar/ahli dapat menjawab pertanyaan, menyelesaikan masalah serta mengambil keputusan yang biasanya dilakukan oleh seorang pakar.

Sistem pakar merupakan suatu ilmu yang mengandalkan kemampuan komputer dari suatu peralatan, dalam hal ini komputer, untuk melaksanakan fungsi atau tugas yang dilakukan manusia. Sistem pakar dirancang dengan meniru proses penalaran pakar dalam berbagai macam masalah yang spesifik. Sistem pakar dapat digunakan oleh pengguna non-pakar untuk meningkatkan kemampuan menyelesaikan masalah.

Sistem pakar didefinisikan sebagai: (1) sistem yang menggunakan pengetahuan manusia dalam komputer untuk menyelesaikan masalah-masalah yang membutuhkan keahlian tertentu; (2) cabang dari kecerdasan buatan yang menggunakan pengetahuan khusus untuk menyelesaikan berbagai masalah pada tingkat pakar manusia; (3) bagian dari program komputer yang dapat memberi saran, menganalisis, dan lain hal yang dapat dilakukan sebagaimana seorang pakar manusia pada umumnya.

Ciri-ciri dari sistem pakar tersebut: (1) terbatas pada domain keahlian tertentu; (2) dapat memberikan penalaran untuk data-data yang tidak pasti; (3) dapat mengemukakan rangkaian alasanalasan yang diberikan dengan cara yang dapat dipahami; (4) berdasarkan pada kaidah tertentu; (5) dirancang untuk dapat dikembangkan secara terpisah; (6) pengetahuan dan mekanisme inferensi jelas terpisah; (7) keluarannya bersifat anjuran; (8) sistem dapat mengaktifkan kaidah secara searah yang sesuai, dituntun oleh dialog dengan pemakai.

Sistem yang dirancang adalah program sistem pakar berbasiskan web untuk rehabilitasi medik penderita skoliosis. Program aplikasi web diakses dengan menggunakan komputer. Sebelum membahas lebih jauh tentang perancangannya, ada baiknya kita pelajari dahulu sepintas mengenai skoliosis.

Skoliosis adalah kelengkungan tulang belakang yang abnormal ke arah samping, yang dapat terjadi pada segmen servikal (leher), torakal (dada) maupun lumbal (pinggang). Sekitar 4\% dari seluruh anak-anak yang berumur 10-14 tahun mengalami skoliosis, 40\%-60\% di antaranya ditemukan pada anak perempuan.

Terdapat tiga penyebab umum dari skoliosis: (1) kongenital (bawaan), biasanya berhubungan dengan suatu kelainan dalam pembentukan tulang belakang atau tulang rusuk yang menyatu; (2) neuromuskuler, pengendalian otot yang buruk atau kelemahan otot, atau kelumpuhan akibat penyakit berikut: cerebral palsy, distrofi otot, polio, osteoporosis juvenil; (3) idiopatik, penyebabnya tidak diketahui. 
Pengobatan yang dilakukan tergantung kepada penyebab, derajat, lokasi kelengkungan, dan stadium pertumbuhan tulang. Jika kelengkungan kurang dari $20^{\circ}$, biasanya tidak perlu dilakukan pengobatan, tetapi penderita harus menjalani pemeriksaan secara teratur setiap enam bulan.

Pada anak-anak yang masih tumbuh, kelengkungan biasanya bertambah sampai 25-30, karena itu biasanya dianjurkan untuk menggunakan brace (alat penyangga) untuk membantu memperlambat progresivitas kelengkungan tulang belakang. Brace dari Milwaukee \& Boston efektif dalam mengendalikan progresivitas skoliosis, tetapi harus dipasang selama 23 jam/hari sampai masa pertumbuhan anak berhenti. Brace tidak efektif digunakan pada skoliosis kongenital maupun neuromuskuler. Namun jika kelengkungan mencapai $40^{\circ}$ atau lebih, biasanya dilakukan pembedahan. Pada pembedahan dilakukan perbaikan kelengkungan dan peleburan tulang-tulang. Tulang dipertahankan pada tempatnya dengan bantuan 1-2 alat logam yang terpasang sampai tulang pulih (kurang dari 20 tahun). Sesudah dilakukan pembedahan mungkin perlu dipasang brace untuk menstabilkan tulang belakang. Kadang diberikan perangsangan elektrospinal, di mana otot tulang belakang dirangsang dengan arus listrik rendah untuk meluruskan tulang belakang.

Ada beberapa tujuan pada rancangan program pakar ini, yaitu: (1) untuk mendiagnosis jenis skoliosis; (2) membantu pengguna khususnya mahasiswa kedokteran dalam memahami konsep dasar ilmu tentang gejala skoliosis dan penerapannya dalam bidang kedokteran; (3) mendapatkan informasi tentang skoliosis lebih mudah karena program berbasis web.

\section{METODE}

Perancangan model perangkat lunak berupa program pendiagnosisan, anjuran pengobatan, dan konsultasi yang didesain oleh pakar. Program yang dirancang akan digunakan untuk mendiagnosis skoliosis berdasarkan gejala dan penyebab.

Dalam merancang program aplikasi sistem pakar, spesifikasi rancangan harus ditentukan lebih dahulu, yaitu sebagai berikut: (1) Modul Utama - modul ini akan ditampilkan pada situs halaman web ketika pengguna pertama kali memasuki situs skoliosis; (2) Modul Scoliosis - modul ini memberikan informasi dan teori mengenai hal-hal yang berkaitan dengan skoliosis; (3) Modul Anatomy - modul ini memberikan informasi mengenai anatomi tulang manusia; (4) Modul Diagnosis - modul ini memberikan informasi mengenai diagnosis yang diberikan oleh pakar; (5) Modul Consultation modul ini memberikan informasi mengenai tanya jawab antara pengguna dengan pakar; (6) Modul FAQ's - modul ini digunakan untuk melihat pertanyaan-pertanyaan yang sering diajukan; (7) Modul More - modul ini berisi artikel dan cerita-cerita penderita skoliosis; (8) Modul About - modul ini berisi data tentang pakar skoliosis dan pembuat program; (9) Modul Admin - modul ini digunakan oleh pakar untuk melakukan pemeliharaan data.

\section{HASIL DAN PEMBAHASAN}

Hal-hal yang dilakukan dalam proses pembuatan program aplikasi sistem pakar untuk mendiagnosis skoliosis adalah sebagai berikut: (1) mengumpulkan materi dan data yang diperlukan dari sumber referensi (pakar); (2) menggunakan data yang diperoleh sebagai basis pengetahuan; (3) membuat aturan-aturan yang digunakan untuk mengambil suatu keputusan; (4) membuat program dengan menggunakan bahasa pemrograman PHP; (5) melakukan dokumentasi. Modul yang terdapat pada aplikasi yang digunakan pada perangkat komputer adalah: 


\section{Modul Utama}

Modul halaman utama ini ditampilkan pada saat pertama kali membuka situs skoliosis. Terdapat beberapa pilihan modul yang akan dipilih dan ditampilkan, yaitu Scoliosis, Anatomy, Diagnosis, FAQ's, More, About, dan Admin.

\section{Modul Scoliosis}

Modul ini menampilkan informasi mengenai skoliosis. Pada modul ini akan ditampilkan beberapa modul yang akan dipilih untuk ditampilkan, yaitu: (1) Modul Theory - menampilkan informasi mengenai skoliosis; (2) Modul Causes and Symptoms - menampilkan gejala dan penyebab skoliosis; (3) Modul Glossary - menampilkan penjelasan istilah dalam penyakit skoliosis.

\section{Modul Anatomy}

Modul ini berisi keterangan mengenai anatomi tubuh manusia

\section{Modul Diagnosis}

Modul ini berisi diagnosis mengenai penyakit skoliosis dan anjuran rehabilitasi mediknya.

\section{Modul Consultation}

Modul ini berisi konsultasi antara pengguna dengan pakar.

\section{Modul FAQ's}

Modul ini berisi jawaban dari pertanyaan-pertanyaan yang sering diajukan.

\section{Modul More}

Modul ini berisi informasi tambahan mengenai skoliosis. Pada modul ini terdapat: Modul Articles yang berisi tentang artikel yang berkaitan dengan skoliosis, Modul Just Like Me yang berisi cerita penderita skoliosis, dan Modul Patient Stories yang berisi pengalaman penderita skoliosis.

\section{Modul About}

Modul ini berisi keterangan mengenai data tentang pakar dan pembuat website.

\section{Modul Admin}

Modul ini digunakan untuk melakukan pemeliharaan data. Pada modul ini terdapat pemeliharan yang mencakup: Modul Manage Data untuk melakukan pemeliharaan data terhadap jenis skoliosis, istilah skoliosis, dan anjuran pakar, Modul Jawab Pertanyaan untuk melakukan konsultasi antara pengguna dengan pakar, dan Modul Edit Data User untuk melakukan pemeliharaan terhadap data pengguna.

Setelah sistem dirancang, selanjutnya dilakukan pembuatan sistem. Spesifikasi perangkat keras yang digunakan dalam pembuatan sistem adalah: Prosesor Duron 800 Mhz, Memory RAM 384 MB, VGA card GeForce2 MX, dan Harddisk berkapasitas 20 GB. Spesifikasi perangkat lunak yang digunakan dalam pembuatan sistem adalah sebagai berikut: sistem operasi Microsoft Windows XP, PHP, Web Server Apache, MySQL, dan Macromedia Dreamweaver MX. Prosedur pembuatan sistem 
ini adalah: (1) menentukan modul dan sistem yang akan digunakan; (2) perancangan database; (3) pembuatan program; (4) pengujian program.

\section{PENUTUP}

Kesimpulan yang diperoleh melalui perancangan program Sistem Pakar Berbasiskan Web untuk Rehabilitasi Medik Penderita Skoliosis adalah: (1) program sistem pakar ini dapat dijalankan dengan baik dan sesuai dengan konsep dasar rancangan; (2) program sistem pakar ini memberikan informasi yang mudah didapat bagi masyarakat karena berbasis web; (3) program sistem pakar ini dapat membantu mahasiswa kedokteran dalam diagnosis skoliosis.

Beberapa saran untuk pengembangan sistem lebih lanjut adalah: (1) penambahan modul referensi pada menu program untuk mempermudah pencarian pakar rehabilitasi medik; (2) pembaharuan data secara periodik untuk meningkatkan kinerja dari program yang sudah dibuat.

\section{DAFTAR PUSTAKA}

Thendean, Helmy. (2004). Catatan Kuliah Sistem Pakar. Program Studi Teknik Informatika Fakultas Teknologi Informasi Universitas Tarumanagara, Jakarta.

Yudatama, Uky. (31 Agustus 2004). Menirukan Keahlian Seorang Pakar. Diakses dari http://www.suaramerdeka.com/harian/0311/10/ragam2.htm.

Yudatama, Uky. (31 Agustus 2004). Teknik Merancang dan Membuat Sistem Pakar. Diakses dari http://www.suaramerdeka.com/harian/0401/26/ragam5.htm. 